DOI https://doi.org/10.32837/app.v0i67.1168

УДК 347

\author{
Ю. Е. Мамедов \\ orcid.org/0000-0002-2364-8438 \\ аспірант кафедри міжнародного права \\ Київського інституту міжнародних відносин
}

\title{
КОНЦЕПЦІЯ ПРАВ ДИТИНИ В ІСЛАМСЬКІЙ ПРАВОВІЙ СИСТЕМІ
}

Сьогодні є стереотипне мислення, що ісламське право та релігія ісламу загалом є протилежністю захисту прав дітей, тому що ісламська концепщія справедливості не співвідносна із правами дітей. Проте до розгляду цього питання потрібно підходити критично. Основним джерелом, з якого слід виходити з ісламської правової бази, є Священний Коран, Сунна, Іджма та Кияс, що в сукупності становлять шаріат. Величезна кількість наукових праць з ісламського права сьогодні дає нам змогу дослідити справжні виміри ісламської правової теорії, що стосуються прав дітей, для зміцнення теоретичного розуміння прав дітей у межах міжнародного корпусу з прав людини.

Хоча захист прав та добробуту дітей виник як одне із перших зобов'язань ісламського права, для їх реалізації були прийняті різні підходи. Деякі з цих підходів викладені нижче.

Заходом, якому сприяє іслам, який також був прийнятий деякими ключовими міжнародними документами з прав людини щодо дітей, є формулювання прав та прав дітей у чітких, однозначних, обов' язкових правових нормах та гарантіях. Згідно з цим підходом, недостатньо лише визнати в принципі, що діти є вразливими і мають право на певні особливі права. Закон повинен позитивно заявити про такі права та надати детальні гарантії. Таку позицію зайняв шаріат із самого початку, тобто просто релігійних та соціальних зобов'язань недостатньо, але це має бути виражено в детальних правових положеннях (Oba, 2007). Це також, схоже, є підходом міжнародних документів із прав людини, оскільки вони встановлюють не лише права дитини, а й захисні заходи, які має ввести держава, щоб забезпечити виконання цих прав.

Варто відзначити, що древній документ, відомий як Хартія Медіни, укладений між Пророком Мухаммедом і жителями міста Медіни в 622 році н.е., який згадується як «перша письмова конституція в ісламі і, можливо, перший конституційний закон у суспільстві», включив у себе поняття прав людини, які можна вивести зі Священного Корану.

Правові норми можуть бути позбавлені сенсу, якщо їх не дотримуватись і не застосовувати. Однак у разі положень такого величезного соціального та культурного значення, як ті, що стосуються добробуту дітей, це вимагає не лише примусових повноважень держави та загрози правових санкцій для здійснення необхідного впливу. Артикуляція прав дітей у правових документах вважається шаріатом лише одним із багатьох заходів, що застосовуються. Звернення до правових санкцій розглядається як останній і необхідний захід. В ісламі закон поєднується з релігією, освітою та етичною спрямованістю. Отже, вважається, що норми права знайдуть своє вираження в суспільстві шляхом узгоджених дій усіх цих впливів на особисту поведінку.

Таким чином, зміст і програма базової освіти в мусульманському суспільстві включають принципи соціальних прав і обов' язків, у тому числі що стосуються дітей, які є частиною повсякденного життя кожного мусульманина. Сури (глави) Священного Корану, деякі основні традиції Пророка Мухаммеда і деякі елементарні релігійні тексти, з якими кожен мусульманин зазвичай знайомиться з раннього віку, надають мусульманам більшу частину того, що необхідно. Він або вона вивчає і засвоює ці зобов'язання, які також є частиною звичаїв мусульманського суспільства. Таким чином, правові положення, наприклад, що стосуються прав і благополуччя дітей, підвищуються до статусу релігійних і соціальних зобов' язань, просте знання яких, не кажучи вже про виконання, дає нагороду від Аллаха.

Цікаво, що неюридичний імператив є помітним підтекстом у деяких основних міжнародних документах із прав людини, що стосуються дітей. Зокрема, Конвенція ООН про права дитини і Хартія африканських дітей не зупиняються на юридичних деклараціях. Вони ви- 
магають, щоб держави-учасники заохочували дітей до навчання і в деталях обговорювали вид освіти, на який має право кожна дитина (African charter on the rights and welfare of the child). Конвенція ООН про права дитини також конкретно передбачає, що його зміст має бути поширеним і широко відомим. Два документи могли б також виграти від положень, які вимагають, щоб знання і значення принципів, які вони втілюють, були включені в шкільну програму в державах-учасницях. На жаль, ці документи не містять таких положень. Однак відповідальність за вжиття заходів із просування цілей цих інструментів лежить на державах-учасницях, кожна з яких має діяти відповідно до ії власної юрисдикції (African charter on the rights and welfare of the child).

Сьогодні і ісламському праві багато суперечок про те, чи заслуговують майбутні ненароджені діти на будь-який правовий захист. Аргументи і контраргументи оберталися навколо того, що було описано як ключове питання, а саме: «В який момент часу виникає людське життя і в який момент суспільство вважає, що таке життя заслуговує правового захисту?» (Fortin, 1988). Спроби відповісти на це питання привели до поширення тривалих філософських суперечок.

Оскільки вони зазнали серйозних наукових досліджень, ми не будемо детально зупинятися на таких дебатах. Проте не можна очікувати, що вже згадані документи такої транснаціональної важливості можуть надати бажаний вплив, якщо вони уникають спірних питань і обмежуються тільки врегульованими проблемами.

Результат полягає в тому, що в ісламському законодавстві ненароджені діти не тільки мають право на правовий захист свого здоров'я та життя, але й вважаються отримувачами певних додаткових прав. 3 метою надання ненародженим дітям законних прав ісламське законодавство вкладає їх у якість, відому як зімма (dhimma).

В ісламському праві зімма визначається як «якість, завдяки якій людина стає придатною для того, що йому [або йй] дано, а також того, чому він [або вона] підпорядковується» (Abdallah, 1978).

Для захисту життя і здоров'я майбутньої дитини ісламське право надає йому або їй певні права згідно з ісламським кримінальним законодавством і законами про делікти. Особи, які вбивають своїх дітей до або після їх народження, прописуються як загублені (Koran, 1990, 6:140). Вбивство дітей є великим гріхом (Koran, 1990, 17:31). Якщо будь-яка особа чинить агресію проти вагітної жінки, в результаті чого вагітність переривається, така особа притягається до відповідальності за вбивство дитини на додаток до будь-якої іншої відповідальності, яку ця особа могла б нести матері. Гурра (ghurra), на думку більшості вчених, є не просто додатковою виплатою матері, а ще й незалежним правом дитини бути успадкованим спадкоємцями. Якщо дитина, мати якої стала жертвою такої агресії, народжується живою, а потім помирає від травми, отриманої в утробі матері, компенсація становитиме повну дійа («криваві гроші»).

Тоді як деякі ісламські правознавці потурають аборту, якщо він відбувається в перші 120 днів вагітності, навіть без будь-якої причини, що становить небезпеку для життя матері, аборт, зроблений в будь-який момент після цього, зазвичай визнається мусульманами незаконним.

Однак ще одне право ненародженої дитини, яке вона отримує тільки побічно, - це обов' язок, який покладений на батька, забезпечувати додаткове харчування вагітної дружини у зв'язку з вагітністю. Більше того, батько повинен робити все, що в його силах, щоби зберегти життя майбутньої дитини (Koran, 1990, 65:6).

Права власності. Правоздатність ненародженої дитини, хоч і часткова, тим не менше дозволяє їй або йому набути майнові права за допомогою заповітів та подарунків, зроблених на його/ії користь та у порядку спадкування.

Складання заповітів і пожертвувань $є$ критичними питаннями в ісламському праві, настільки, що існують томи творів на цю тему. Хоча за ісламським правом хіба (подарунок) i васійя (спадщина) повинні прийматися обдаровуваним або у спадок, є винятки в разі ненароджених дітей. Взагалі кажучи, для того, щоб васійя і хіба вступили в силу, ненароджена дитина повинна існувати на момент оголошення заповіту або дарунка. Це означає, що якщо мати - заміжня жінка, дитина повинна народитися протягом шести місяців після складання заповіту або дарування подарунка, оскільки це мінімальний період вагітності. 
Хоча майно, яке ненароджена дитина набуває даруванням чи заповітом, надходить до неї через добровільний вчинок іншої особи, ії право на спадщину є обов' язковим законним правом. Ненароджена дитина має право, як і будь-яка інша особа, на встановлену частку в спадщині ії померлого батька. Дитина отримує повну частку, ніби вона була присутня на момент смерті. Як і у разі з подарунками та заповітом, право на спадкування майбутньої дитини регулюється тими самими двома умовами:

1) дитина повинна бути зачатою на момент смерті родича померлого;

2) вона повинна народитися та фактично бути живою.

Після народження дитина набуває основних соціальних прав. Серед них виділяють такі.

Право на походження. Це право дитини на законне народження (від батьків, які перебувають в законному шлюбі). Позашлюбне народження позбавляє дитину цього права. Якщо батько дитини невідомий, інші батьки не можуть претендувати на його батьківські права навіть шляхом прямого або непрямого усиновлення. В Корані говориться, що усиновлена дитина не $\epsilon$ справжнім нащадком усиновителя, він всього лише $є$ братом по вірі.

Право на походження породжує також право знати біологічних батьків. Іслам робить акцент на утриманні сімейної установи і бажає, щоб кожна дитина, наскільки це можливо, виховувалася ії природними батьками. Він також вимагає, щоб кожна дитина зберігала свою справжню особистість та підтримувала юридичний зв' язок із природженими батьком та матір'ю. Сироті також ніколи не може бути відмовлено в його початковій особистості. Це право включає необхідність простежити свій генетичний родовід для медичних цілей, що також $\epsilon$ підставою для занепокоєння, пов'язаного з кровозмісними шлюбами чи відносинами.

Така позиція ісламського права виявляється в тому, що нечітка ланка, яка створюється шляхом усиновлення, повністю відкидається. У Священному Корані сказано, що усиновлені діти не $є$ справжнім потомством усиновителів. Якщо природні батьки усиновлених дітей відомі, ïx потрібно зв'язати з ними (Koran, 1990, 33:4-6). В іншому разі не потрібно створювати жодної юридичної фікції, а дітей без батьків виховуватимуть інші члени мусульманської громади. У листах Священного Корану написано: «І не зробив твоїми синами тих, кого ти вважаєш [своїми синами]. Це лише висловлювання ваших вуст. Але Аллах говорить правду, і він показує шлях. Проголосіть їх справжнє походження. Це буде більш справедливо в очах Аллаха. А якщо ви не знаєте їхніх батьків, то [вони] є вашими братами по вірі» (Koran, 1990, 34:4).

Усиновлення, як правило, заборонено, нібито тому, що це порушує структуру сімейних відносин, яку ісламське законодавство визнає та вкладає в неї законні права та обов'язки (al-‘Ātī, 2007, с. 194-195). У деяких суспільствах, таких як доісламська Аравія, усиновлення відбувалося паралельно з певними наслідками практики, такими як право сім'ї на відмову від одного з ії членів або право особи на відмову від своєї біологічної сім'ї, обидва з яких отримували підвищення можливістю усиновлення в іншу сім'ю. Ісламське законодавство забороняє всі ці звичаї та вимагає, щоб кожна людина зберігала свою природну особистість (Koran, 1990, 33:4-6).

Однак заборона усиновлення не заважає одній особі взяти на себе відповідальність за виховання дитини іншої, що є заслугою в ісламі, що називається «кафала» та широко практикується і може навіть стати обов'язком. Наприклад, той, хто знайшов підкидька, зобов' язаний піклуватися про нього та виховувати так, як він би виховував своїх дітей. Подібним чином, якщо природні батьки не здатні виховувати свою дитину, ісламське рішення - це не усиновлення. Мусульманське суспільство має допомогти їм, якщо вони потребують лише матеріальної допомоги, або ж щоб дитина була влаштована до інших батьків, які є якомога тіснішими родичами дитини. За ісламським законодавством, нові батьки не будуть повністю витісняти природних батьків, а виконуватимуть їхню функцію (al-'Ātīi, 2007, c. 195-196).

Право на визнання мусульманським суспільством. В ісламі народження дитини чоловічої або жіночої статі є приводом для великого свята. Батькам рекомендується провести тахнік - покласти що-небудь солодке, наприклад фініки або мед, у рот і помолитися за новонародженого. За законами шаріату, дитина має право на добре ім'я, яке не повинне мати поганої або неприємної конотації.

Щоб завершити святкування, вітаючи новонароджену дитину, батькам рекомендується зробити хадана (дати дитині його/ії кімнату), особливо після того, як він/вона виросте. 
Право на життя. Для реалізації головних прав дитини є кілька вимог, таких як ії право на життя та загальний догляд. Іслам гарантував право на життя всім людям, за винятком чітко визначених злочинів у шаріаті, через які людина втрачає своє право на життя (Koran, 1990, 5:32).

Право на загальний догляд. Маленька дитина має свої фізичні потреби, а також емоційні та духовні потреби. Батьки, опікуни та піклувальники повинні навчати свою дитину добрим манерам у всьому. Аллах сказав: «Батько дитини несе витрати на їжу та одяг матері на розумній основі» (Koran, 1990, 2:233).

Право на базову освіту. В ісламському суспільстві, однак, освіта - це не просто право для окремих людей, ісламське право дійсно вимагає, щоб уряд підготував і надав всі кошти, які допоможуть людям в ісламському суспільстві отримати кращу освіту (The Book of Sunnah). Краща освіта вважається видом джихаду (ісламської боротьби), яку винагороджує Аллах.

Більше того, іслам вважає незаконним приховування будь-яких корисних знань, якими володіють, не ділячись з іншими (Arfat, 2013). Таким чином, очевидно, що це основне право кожної дитини на отримання більш якісної і корисної освіти.

Право на справедливе та рівне ставлення. Діти також мають право на справедливе і рівне ставлення до них. Жодна дитина не повинна отримувати пріоритет чи будь-який тип переваг над іншими з погляду гарної поведінки та доброго поводження, а також щодо подарунків, грантів, права власності чи спадщини (Arfat, 2013). Недобросовісне ставлення до дітей може призвести до поганої поведінки одне щодо одного або щодо обох батьків у майбутньому або в похилому віці.

Право на фізичне виховання. В ісламській перспективі, як сказав Ібн Сіна - дуже видатний мусульманський філософ, освіта не нехтує фізичним розвитком і всім, що з нього випливає: фізичними вправами, їжею і питвом, сном і чистотою. За його словами, цілями освіти є загальний ріст особистості: фізичний, розумовий та моральний, з подальшою підготовкою цієї людини до життя в суспільстві шляхом обраної професії відповідно до ії схильностей. Тоді іслам надає можливості як фізичні, так і духовні.

Згідно з положенням ісламського права, дитина має також фінансові права. Серед них виділяють такі.

Право на існування (нафака). Для виконання вищезазначених прав дитина потребує фінансового забезпечення. Шаріат (ісламське право) прописав, що батько несе відповідальність за такі фінансові вимоги (нафака) (Koran, 1990, 2:223). Обов' язок батьків - помірковано витрачати на добробут своєї дитини (Koran, 1990, 25:67).

Право на процвітання та спадщину. Загальновідомо, що шаріат (ісламський закон) підтверджує право новонародженої дитини на володіння майном та спадщиною (Koran, 1990, 4:11). Більше того, шаріат зберіг таке право задовго до народження, ще будучи плодом. Якщо батько помирає, коли мати вагітна, від заповіту (або спадщини) не можна відмовлятися, поки дитина не народиться.

Наостанок варто підкреслити, що в ісламському праві поняття прав та обов' язків - особливо в сім'ї - $є$ взаємними. Такі права та обов'язки включали би права на утримання та спадкування. Однак така взаємність не обмежується матеріальними правами. Зобов'язання батьків виховувати своїх дітей, наприклад, відповідає обов'язку дитини перед ними іхсан, який включає «доброту, довіру, благоговіння» щодо нього/неї (al-‘ Ātī, 2007, c. 205). Іхсан також включає в себе повагу та послух, але вони повинні здійснюватися в межах закону. Взагалі іхсан - це відповідальність мусульманина за досягнення досконалості або переваги в поклонінні, так що мусульмани намагаються поклонятися Аллаху, як якщо б вони бачили Його, i хоча вони не можуть бачити Його, вони, безсумнівно, вірять. Він постійно спостерігає за ними. Наприклад, дитина не повинна бути настільки покірною своїм батькам, щоб вона нехтувала своїм основним обов'язком, а саме послухом Аллаху (al-‘Āti, 2007, c. 134).

В ісламському праві обов'язок захисту прав та добробуту дітей також піднімається на моральну площину як частина багатовимірного підходу, який ісламський закон застосував у цій галузі. Піклуватися про дітей, проявляти до них співчуття, виховувати та навчати їх добрим манерам - це в ісламі одна з релігійних справ, що заслуговують на велику похвалу. 
Виховання дисциплінованої і праведної дитини, яка виросте доброю і співчутливою до своїх батьків, пророк Мухаммед вважає одним із трьох добрих вчинків, за які людина продовжує заробляти винагороду ще довго після смерті. Щодо цієї традиції пророк Мохаммед каже: «Коли людина помирає, ії вчинки закінчуються, крім трьох: повторюване милосердя, знання, якими користуються люди, або благочестива дитина, яка молиться за нього/неї» (The Book of the Sunnah). I справді, правильне виховання дітей перетворює їх на цінні активи для суспільства. Усі їхні добрі вчинки, молитви, які вони роблять за своїх померлих батьків, моральні норми, яких вони дотримуються, і страх Божий, який вони виявляють у всіх своїх діях, стають постійним джерелом винагороди для померлих батьків. Згідно з іншою традицією, Пророк Мухаммед розглядав відданість добробуту дітей як таку діяльність, якою мусульмани повинні займатися в змагальному дусі, і пророкував, що мусульманська громада може отримати своє ім'я серед інших громад своєю добротою до дітей (al-‘Ạtī, 2007, C.198).

У гуманітарному ісламському праві також прописані головні права дитини. Серед них першочерговими вважаються такі.

Право дитини не використовуватися на війні до досягнення відповідного віку. Про це згадується в Сунні (традиція), де Посланник Аллаха встановлює вік до п'ятнадцяти років. Ібн Омар сказав: «Посланник Аллаха (мир йому і молитвам) оглянув мене для бою в день Охуда, але не погодився дозволити мені битися, і мені тоді було чотирнадцять років. Він знову оглянув мене в день Хандака і дозволив мені воювати. На той момент мені було п'ятнадцять років» (Nabulsi). Пророк, таким чином, заважав Ібн Омару, перш ніж йому було п'ятнадцять років, вступати в бій, бо бойові дії становлять небезпеку для неповнолітніх, які не здатні битися.

Право дітей на захист під час війни та катастрофи. Іслам зосереджується на захисті дітей-іммігрантів у надзвичайних ситуаціях та в умовах катастроф, надаючи їм притулок та утримання (History of Islam, 2011). Забороняється завдавати шкоди жінкам та дітям під час війни, за винятком одного випадку. Якщо жінки та діти воюють під час війни, вчені фукаха погоджуються щодо допустимості їх убивства. За словами Ібн Хазма, «вбивство жінок і дітей $\epsilon$ харамом, якщо тільки вони не беруть участь у війні» (Arlandson, 2016).

Нарешті, в шаріаті введено положення про дітей та тих, кого не можна вбивати серед ворогів (Islamic Supreme Council of America, 2016). Це права дитини, визначені ісламським шаріатом у текстах Корану та Сунни, які захищають дитину від нехтування, жорстокості та експлуатації та гарантують безпеку та соціальну стабільність.

Отже, права дітей та гарантії їхнього благополуччя в ісламському праві становлять величезну тему, охоплюючи всі аспекти життя дитини. Той факт, що шаріат включає не тільки закон, але також релігію та етику, дає змогу запропонувати створену ним систему, багатовимірний підхід, що охоплює всю особистість дитини. Ісламське право детально розглядає законні права дітей, але не зупиняється на простих юридичних деклараціях. Ісламським правом передбачаються примусові санкції, а також релігійні та соціальні заходи для сприяння добробуту дитини. Згідно з ісламським законодавством, як було продемонстровано, не лише після народження дитини вона починає набувати законних прав. Закон йде далі, створюючи захисний щит навколо ненародженої дитини з моменту зачаття і навіть інвестуючи в неї здатність отримувати додаткові вигоди.

Іслам як цілісна релігія надає дитині багато прав і стосується фізичного, емоційного, соціального та духовного благополуччя. Дитина має право на релігійне навчання, освіту та духовне керівництво. Батьки відіграють роль не лише через свої зобов'язання, держава та громадянське суспільство також відіграють роль завдяки своїй соціальній відповідальності. Освіта, сприятлива для дітей, може бути проявом соціальної відповідальності організації громадянського суспільства за реалізацію прав дитини.

\section{Лimepamypa}

Abdallah, A.A. (1978). Al-Ahliyyah: or legal capacity in Islamic law. Centre for Islamic Legal Studies, Ahmadu Bello University.

al-'Ạtī Hammūdah 'Abd. (2007). Islam in focus = Ta' rīf bi-al-Isläm. Dar al-Manarah.

Arfat, S. (2013). ISLAMIC PERSPECTIVE OF THE CHILDREN'S RIGHTS : AN OVERVIEW. Asian journal of social sciences and humanities, 2, 297-305. 
Arlandson, J. (2016). Jihad: The truth about the rules of Islamic warfare. https://www.answering-islam.org/ Authors/Arlandson/jihad.htm.

Fortin, J. E. (1988). LEGAL PROTECTION FOR THE UNBORN CHILD. The Modern Law Review, 51(1), 54-55. https://doi.org/10.1111/j.1468-2230.1988.tb01743.x

Islamic Supreme Council of America. (2016). http:/ / www.islamicsupremecouncil.org/ understanding-islam/ legal-rulings/52-understanding-islamic-law.htm.

Koran. (1990). The Koran. Penguin.

Nabulsi. Interpretation of the Quran: Surah Al-Imran (3)- Lesson (31)- Verse [121]: 'Uhud' battle. Nabulsi Encyclopedia of Islamic Science. https://alhudagroup-tr.com/web/en/articles/ 8864.

Oba, A. (2002). Islamic Law as Customary Law: The Changing Perspective in Nigeria. International and Comparative Law Quarterly, 51(4), 817-850. doi:10.1093/iclq/51.4.817

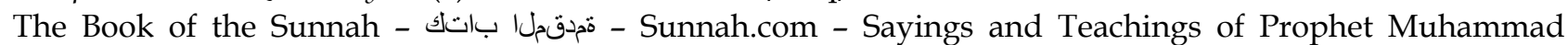

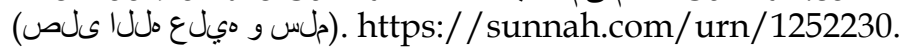

The Significance of the Hijrah (622 CE). History of Islam. (2011, December 15). https://historyofislam.com/ contents/the-age-of-faith/the-significance-of-the-hijrah-622-ce/.

\section{Анотація}

Мамедов Ю. Е. Концепція прав дитини в ісламській правовій системі. - Стаття.

Встановлено, що захист прав та добробуту дітей виник як одне із перших зобов'язань ісламського права, для реалізації чого були прийняті як правові, так і неправові підходи. Дитина має набір прав, що віднесені до соціальних, освітніх та фінансових прав. Деякі соціальні права дитини виникають навіть до ії фактичного народження. Освітні права охоплюють права на життя, загальний догляд та соціалізацію, а також право на базову освіту, справедливе та рівне ставлення та фізичне виховання. Фінансові права охоплюють права на майно та спадщину. Для того, щоб дозволити дітям користуватися своїми правами, гарантованими ісламом, батьківська опіка відіграє важливу роль. Але держава та організації громадянського суспільства також мають зіграти ключову роль у цьому питанні. Освіта, сприятлива для дітей, може бути проявом соціальної відповідальності організації громадянського суспільства за реалізацію прав дитини. Права бути усиновленим в ісламському праві немає, проте є практика кафала, яка делегує відповідальність за виховання дитини іншим батькам. Встановлено, що шаріатом дитині надається право знати своїх біологічних батьків. Доведено, що права дітей в ісламі корелюють з тими, які забезпечуються з боку міжнародного гуманітарного права. Насамперед такими є право дітей на захист під час війни та катастрофи та право дитини не використовуватися на війні до досягнення відповідного віку.

В ісламському праві поняття прав та обов' язків - особливо в сім'ї - є взаємними. Така взаємність не обмежується тільки матеріальними правами. Зобов'язання батьків виховувати своїх дітей, наприклад, відповідає обов'язку дитини перед ними «іхсан», який включає «доброту, довіру, благоговіння» щодо нього/неї. Іхсан також включає в себе повагу та послух, але вони повинні здійснюватися в межах закону.

Ключові слова: ісламське право, права дітей в ісламі, зімма, освітні, соціальні, фінансові права, іхсан.

\section{Summary}

Mammadov Yu. E. The concept of children's rights in the Islamic legal system. - Article.

It was established that the protection of the rights and well-being of children emerged as one of the first obligations of Islamic law, for the implementation of which both legal and non-legal approaches were adopted. The child has a set of rights related to social, educational and financial rights. Some of the child's social rights arise even before her/his actual birth. Educational rights cover the rights to life, general care and socialization, as well as the right to basic education, fair and equal treatment and physical education. Financial rights cover property and inheritance rights. In order to enable children to enjoy their rights provided by Islam, parental care plays an important role. But the state and civil society organizations also have to play a key role in this matter. Education conducive to children can be a manifestation of the social responsibility of a civil society organization for realizing the rights of the child. There is no right to be adopted in Islamic law, but the practice of kafalah delegates responsibility for raising a child to other parents. It has been established that Sharia law gives a child the right to know his/her biological parents. It has been proven that the rights of children in Islam are correlated with those provided by international humanitarian law. First of all, these are the right of children to protection in times of war and catastrophe and the right of a child not to be used in war until they reach the appropriate age.

In Islamic law, the concept of rights and responsibilities - especially in the family - are reciprocal. This reciprocity is not limited to substantive rights only. The obligation of parents to educate their children, for example, corresponds to the obligation of the child to them ihsan, which includes "kindness, trust, reverence" towards him / her. Ihsan also includes respect and obedience, but these must be carried out within the framework of the law.

Key words: Islamic law, children's rights in Islam, dhimma, educational, social, financial rights, ihsan. 